\title{
Strength and Chronic Obstructive Pulmonary Disease
}

\author{
Pedro Victor Nogueira de Souza and Alexandre Lima de Araújo Ribeiro* \\ Faculty of Physical Education, University of Brasilia, Brazil
}

Submission: January 11, 2020; Published: January 22, 2020

*Corresponding author: Alexandre Lima de Araújo Ribeiro, Professor in Faculty of Physical Education, University of Brasilia, Brasília, Brazil

\section{Introduction}

Muscle strength is a physical capacity that is associated with good health and consequently better quality of life, mental health, among other benefits. Therefore, muscle strength has been indicated as an important marker of mortality Cooper, Kuh, Hardy, \& Mortality Review Group [1]. A way to maintain and increase muscle strength is Resistance Training (RT), which can be performed with machines, dumbbells, free weights, elastic bands, among other specific materials for muscle overload Ratamess [2]. The RT (or strength training) can improve fitness and physical performance Ratamess [2]. In addition, the RT can decrease the risk of mortality from various causes Kim [3]; Saeidifard [4]. However, to reach the expected goal with RT there are variables to be manipulated and health conditions to be taken into account Fleck \& Kraemer [5].

\section{Strength \& disease}

Some diseases can alter the individual's physical capacities, such as Chronic Obstructive Pulmonary Disease (COPD) affects the muscles, thus affecting strength. The muscle dysfunction caused by COPD includes peripheral and respiratory muscles. The peripheral muscle dysfunction is associated with fitness and physical performance in physical activities usually resulting in reduction muscle strength, quality of life, what consequently with elevated health-care use and mortality risk Maltais [6]. Already the respiratory muscle dysfunction limits the skeletal muscle performance in physical exercise by metabolic and cardiorespiratory factors during physical exercises, and normally the dyspnea is one of the main causes of these limitations Stendardi, Binazzi, \& Scano, [7]. Therefore, the treatment of the dyspnea can be one form of COPD combat or delay. And one form of treatment of the dyspnea is strength training. As already show in several studies upper and lower limb muscle strength and endurance to decrease in patients with COPD as the obstruction level increases. However, the strength training can be improving not only peripheral muscle strength and activities daily living performance but decreases dyspnea during exercises and activities of daily living Calik-Kutukcu [8]; Kaymaz [9]; Miranda, Malaguti, \& Corso, [10]. Liao [11] in your systematic review with meta-analysis showed that dyspnea scale scores, skeletal muscle strength, and lung function improved following resistance training. Thus, incorporate the upper limb strength training in pulmonary rehabilitation is recommended to reduce dyspnea Kruapanich [12]. So as shown increasing of the muscle strength is effective strategy not only to reduce all-cause mortality risk but also is a reliable and feasible treatment for COPD patients.

\section{Conflict of Interest}

None.

\section{Funding Information}

None.

\section{References}

1. Cooper R, Kuh D, Hardy R, Mortality Review Group; FALCon, HALCyon Study Teams (2010) Objectively measured physical capability levels and mortality: systematic review and meta-analysis. BMJ 341: c4467.

2. Ratamess NA, Alvar BA, Evetoch TK, Housh TJ, Kibler W, et al. (2009) Progression Models in Resistance Training for Healthy Adults. Medicine \& Science in Sports \& Exercise 41(3): 687-708.

3. Kim Y, White T, Wijndaele K, Westgate K, Sharp SJ, et al. (2018) The combination of cardiorespiratory fitness and muscle strength, and mortality risk. Eur J Epidemiol 33(10): 953-964.

4. Saeidifard F, Medina-Inojosa JR, West CP, Olson TP, Somers VK, et al. (2019) The association of resistance training with mortality: A systematic review and meta-analysis. Eur J Prev Cardiol 26(15): 16471665.

5. Fleck SJ, Kraemer WJ (2017) Fundamentos do Treinamento de Força Muscular $\left(4^{\text {th }}\right.$ ed). Porto Alegre: Artmed Editora.

6. Maltais F, Decramer M, Casaburi R, Barreiro E, Burelle Y (2014) An Official American Thoracic Society/European Respiratory Society Statement: Update on Limb Muscle Dysfunction in Chronic Obstructive Pulmonary Disease. Am J Respir Crit Care Med 189(9): e15-e62.

7. Stendardi L, Binazzi B, Scano G (2007) Exercise dyspnea in patients with COPD. Int J Chron Obstruct Pulmon Dis 2(4): 429-439. 
8. Calik-Kutukcu E, Arikan H, Saglam M, Vardar-Yagli N, Oksuz C (2017) Arm strength training improves activities of daily living and occupational performance in patients with COPD. Clin Respir J 11(6): 820-832.

9. Kaymaz D, Candemir IÇ, Ergün P, Demir N, Taşdemir F (2018) Relation between upper-limb muscle strength with exercise capacity, quality of life and dyspnea in patients with severe chronic obstructive pulmonary disease. Clin Respir J 12(3): 1257-1263.

10. Miranda EF, Malaguti C, Corso SD (2011) Peripheral muscle dysfunction in COPD: lower limbs versus upper limbs. J Bras Pneumol 37(3): 380388.
11. Liao WH, Chen JW, Chen X, Lin L, Yan HY (2015) Impact of Resistance Training in Subjects With COPD: A Systematic Review and MetaAnalysis. Respir Care 60(8): 1130-1145.

12. Kruapanich C, Tantisuwat A, Thaveeratitham P, Lertmaharit S, Ubolnuar N (2019) Effects of Different Modes of Upper Limb Training in Individuals with Chronic Obstructive Pulmonary Disease: A Systematic Review and Meta-Analysis. Ann Rehabil Med 43(5): 592-614.

Your next submission with Juniper Publishers will reach you the below assets

- Quality Editorial service

- Swift Peer Review

- Reprints availability

- E-prints Service

- Manuscript Podcast for convenient understanding

- Global attainment for your research

- Manuscript accessibility in different formats ( Pdf, E-pub, Full Text, Audio)

- Unceasing customer service

Track the below URL for one-step submission https://juniperpublishers.com/online-submission.php 